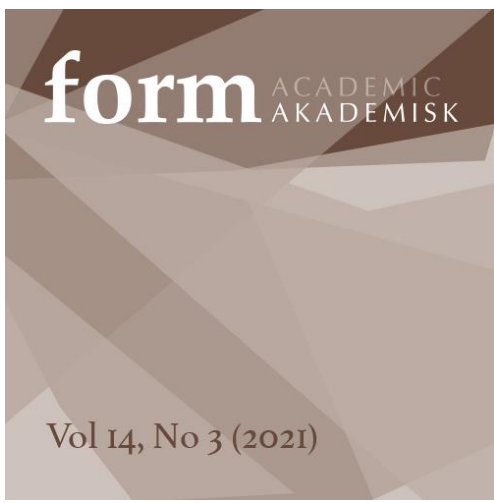

\author{
Arild Berg \\ Professor (Dr. art) \\ OsloMet - storbyuniversitetet \\ arildber@oslomet.no
}

Alfredo Carella

Førsteamanuensis (PhD)

OsloMet- storbyuniversitetet alfcar@oslomet.no

Marius Lysebo

Prodekan for utdanning, Førsteamanuensis (PhD)

OsloMet- storbyuniversitetet marlys@oslomet.no

Liv Merete Nielsen Professor emerita (Dr. ing) OsloMet- storbyuniversitetet livmn@oslomet.no

\title{
Bærekraft i profesjonsutdanninger
}

\section{Gap mellom strategi og programplaner?}

\section{SAMMENDRAG}

Utdanning er en nøkkel til varige endringer i samfunnet. I denne studien bruker vi teori fra bærekraft og didaktikk for å sette søkelys på utdanning av produktdesignere, lærere og ingeniører ved Fakultet for Teknologi, kunst og design (TKD) i lys av OsloMets overordnede strategi om velferd og bærekraft. Empirien bygger på læringsutbyttebeskrivelser fra programplanene for 2019 og 2020 for disse profesjonsutdanningene og er analysert med utgangspunkt i Goodlad og STAUNCH-kategoriene. Alle de analyserte profesjonsutdanningene har integrert bærekraft i sine programplaner. Bærekraft er tydeligst artikulert i programplanen for Produktdesign. Det betyr imidlertid ikke at bærekraft er uartikulert for lærer- og ingeniørutdanningene. Disse utdanningene er styrt av nasjonale rammeplaner der bærekraft inngår på en overordnet og forpliktende måte. Miljøperspektivet er imidlertid tydeligere artikulert $i$ planene enn det økonomiske- og det sosiale perspektivet på bærekraft.

Nøkkelord:

STAUNCH, Goodlad, bærekraft, strategi, programplaner.

\section{INTRODUKSJON - STRATEGI VED OSLOMET}

Verden står overfor store og komplekse utfordringer knyttet til miljø og bærekraft som må Iøses i fellesskap. I OsloMet - storbyuniversitetet (OsloMet) sin strategiske plan Strategi 2024 står både velferdsperspektivet og samfunns-relevans sentralt (Høgskolen i Oslo og Akershus, 2017), og i langtids- 
planen for 2019-2021 har OsloMet et uttalt ønske om å bygge utdanning og forskning på FNs bærekraftsmål (OsloMet, 2019a, s.7). Gjennom OsloMet sin handlingsplan Bærekraftig utvikling for det 21. århundre har visjonen om bærekraft innen utdanning blitt konkretisert på følgende måte: «Alle studier har definert sin rolle og funksjon i forhold til å bygge oppunder og integrere bærekraftsmålene» (OsloMet, 2020a, s. 8). Videre har OsloMet listet opp hvilke programmer og emner som spesielt bidrar til bærekraftig utvikling, på bachelor, master og PhD nivå. De programmene som er listet opp i mai 2021 er tre bachelorprogram: Energi og miljø $i$ bygg, Produktdesign og Utviklingsstudium. To av disse utdanningene er tilknyttet Fakultet for teknologi, kunst og design (TKD).

TKD utdanner produktdesignere, faglærere i design, kunst og håndverk og ingeniører. Alle disse profesjonene har en klar samfunnsfunksjon både knyttet til teknologiforståelse og kultur. Vårt samfunn og vår velferd er tuftet på at vi stoler på at hus og broer ikke faller sammen og at mekanikken som løfter en heis klarer vekten den er beregnet for. Vi forventer at produkter vi omgir oss med er funksjonelle, brukervennlige og estetisk tiltalende. Vi forventer også at barn og unge har kvalifiserte lærere slik at de kan tilegne seg grunnleggende formgivnings- og teknologiforståelse og generell kompetanse for videre studier og for å skaffe seg en jobb og dermed klare seg i samfunnet.

De fagdidaktiske valgene som gjøres i utarbeiding av programplaner ved universitet og høg-

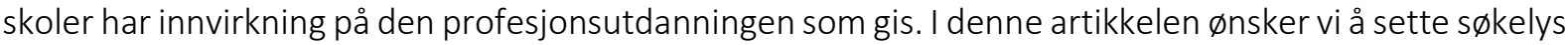
på utdanning av produktdesignere, lærere og ingeniører ved TKD i lys av OsloMets overordnede mål om velferd og bærekraft. Vi spør: Hvordan er bærekraft synlig i programplaner for profesjonsutdanninger ved OsloMet?

\section{EMPIRI, METODE OG TEORIGRUNNLAG}

Vi tar utgangspunkt i begrepet bærekraft slik det er beskrevet i Brundtland-rapporten Our Common Future fra 1987 der både miljø, økonomi og sosial utvikling er integrert. Rapporten fremhever at verdenssamfunnet må sikre at behovene til dagens mennesker blir dekket uten at dette svekker grunnlaget for framtidige generasjoner til å få dekket behovene sine (World Commission on Environment and Development, 1987).

United Nations Educational, Scientific and Cultural Organization (UNESCO) utropte perioden 2005-2014 til tiåret for Education for sustainability. I sluttrapporten fra 2014 ble det slått fast at det var langt igjen før målene var nådd (UNESCO, 2014). Det er med andre ord ikke alltid samsvar mellom hva som ønskes på ideologisk og politisk nivå og hva som gjennomføres i den konkrete utdanningen.

I 2008 ble bærekraft løftet frem som et overordnet mål for all designutdanning gjennom Kyoto design declaration som ble undertegnet på verdenskonferansen til organisasjonen CUMULUS (International Association of Universities and Colleges of art, design and media). Designfeltet mangler ikke litteratur som løfter frem gode intensjoner om hvordan designere kan bidra til en mer miljøvennlig fremtid (Papanek, 1971; Cooper, 2005). Utfordringen ligger i å implementere miljøaspektet i praksis, både i produksjon av produkter og i forhold til forbrukeres etterspørsel, vedlikehold og avhending av produkter.

Det potensialet som ligger i et designrelatert og kulturelt perspektiv på bærekraft har bare delvis blitt vektlagt i grunnskolens gjennomførte praksis, til tross for at den overordnede generelle delen av læreplanen allerede i 1994 fremmet miljøperspektivet i alle fag (Kirke-, utdannings- og forskningsdepartementet, 1994). At miljøperspektivet skal inn i alle fag i grunnskolen, er videreført i de nye læreplanene for grunnskolen som ble innført høsten 2020 ved at bærekraftig utvikling er et tverrfaglig tema (Meld. St. 28 (2015-2016)).

I 2018 publiserte Thürer, Tomašević, Stevenson, Qu og Huisingh en sammenstilling av 247 artikler om bærekraft og ingeniørutdanning, inkludert åtte casestudier fra våre naboland (seks fra Sverige og to fra Danmark). Motivasjonen for sammenstillingen beskrives slik: «...it is unclear where we are on our journey towards introducing and applying sustainability concepts, approaches, tools and paradigms within engineering education» (Thürer et.al, 2018, p.609). Det ble ikke gjort fors $\varnothing k$ på å systematisere informasjon om hvilke bærekraftstema som ble undervist, men fokusert på hvordan 
bærekraft ble introdusert i de eksisterende ingeniørprogrammene. I tråd med tidligere studier (Kamp, 2006) ble fire vanlige fremgangsmåter identifisert:

1. Bærekraft integreres i eksisterende (tradisjonelle) ingeniøremner

2. Nye emner utvikles

3. Bærekraft introduseres som en valgbar spesialisering

4. Bærekraft omhandles ved å introdusere et nytt prosjekt

Lite er kjent om hvor vellykket de forskjellige måtene å integrere bærekraft på har vært. Intervjuer med enkeltstudenter har vist $\varnothing$ kt bevissthet om bærekraft, men Thürer et al. konkluderer med at «... surveys were (i) not comparable; and, (ii) rather subjective» (2018, p. 614).

For å kunne besvare hvordan bærekraft er synlig i utdanningen av produktdesignere, lærere og ingeniører ved TKD/OsloMet har vi valgt å analysere programplaner med tilhørende læringsutbyttebeskrivelser. Empirien som ligger til grunn finner vi i programplanene for 2019 og 2020 for bachelorstudiene Produktdesign, Faglærer i design, kunst og håndverk, Energi og miljø i bygg, Maskiningeniør, Elektronikkingeniør, Bioteknologi- og kjemiingeniør. Gjennomgang av programplanene er gjort med utgangspunkt i analyseverktøyet STAUNCH som er forkortelsen for Sustainability Tool for Assessing UNiversities' Curricula Holistically (Lozano \& Young, 2013). STAUNCH ble utviklet ved Faculty of Business og Faculty of Environment ved University of Leeds som et verktøy for å hjelpe universiteter til å evaluere i hvilken grad deres studieplaner bidrar til bærekraftig utvikling (Lozano, 2010). STAUNCH inneholder 36 tema knyttet til bærekraft under følgende overskrifter; 1) økonomisk perspektiv, 2) miljøperspektiv, 3) sosialt perspektiv og 4) 'Cross-cutting themes' som integrerer økonomi, miljø og sosialt perspektiv. De 36 punktene er konkrete, og det har ikke vært mulig å finne så konkrete formuleringer i de analyserte utdanningenes programplaner og læringsutbyttebeskrivelser. Det betyr ikke nødvendigvis at disse perspektivene ikke er til stede, men at de er innbakt i mer overordnede formuleringer. Både lærerutdanningen og ingeniørutdanningene har slike overordnede nasjonale retningslinjer. Noen steder har vi derfor funnet det $n \varnothing$ dvendig å sitere fra disse. Selv om utdanningene i denne studien er ulike, så anser vi allikevel at STAUNCH er et verktøy som kan bidra til å synliggjøre likheter og forskjeller som grunnlag for forbedringer.

Læringsutbyttebeskrivelsene for programmene har blitt gjennomgått for å unders $\varnothing$ ke hvorvidt perspektivene i STAUNCH-systemet nevnes, beskrives eller diskuteres. Resultatene av analysene, spesielt likheter og forskjeller, drøftes deretter og gir grunnlag for å synliggjøre særtrekk og utfordringer med å integrere bærekraftsperspektiv i de involverte programmene på TKD, alt i lys av OsloMet sin overordnede strategi om bærekraftig utvikling. Forfatterne kjenner godt til de utdanningene som er analysert ved at de har deltatt i programplanarbeid og undervist ved flere av dem.

Analysen er begrenset til formelt vedtatte strategi-, ramme- og programplaner, her omtalt som vedtatt nivå (Goodlad et al, 1979; Nielsen, 2019). Analysen omhandler ikke lærernes tolkning av læreplanene, undervisningen (gjennomført nivå) eller studentenes læring (erfart nivå). Ikke fordi studentenes læring er uinteressant, men fordi det fordrer en annen empiri enn den som ligger til grunn for denne artikkelen. I drøftingen vil ideologiske nivå i noen grad bli trukket inn (Goodlad et al 1979; Nielsen, 2019).

\section{PROFESJONSUTDANNINGER}

Fakultet for teknologi, kunst og design (TKD) har i overkant av 4000 studenter. Utdanningene som er under lupen i denne artikkelen har til sammen 1300 studenter, og representerer bredden av TKDs utdanningsportefølje. Profesjonene og utdanningene er svært ulike, men forventes alle å bygge oppunder FNs bærekraftsmål og OsloMet sin strategi ved å gi innhold og mening til begrepet bærekraft for de ulike profesjonene. 


\section{Produktdesign}

Bachelor i Produktdesign er en treårig utdanning med om lag 43 studenter i hvert kull. Studiet innlemmer designkompetanse i samfunnet i bred forstand på en måte som inkluderer håndverk, digitale produksjonsmetoder, tjenestedesign og prosjektledelse. I utdanning for Produktdesign er bærekraft og innovasjon to av de seks mest sentrale fagområdene som gjentas systematisk gjennom studiet, i ulike kontekster. I programplanen for bachelorstudiet i Produktdesign er bærekraft og innovasjon knyttet til den faglige tradisjonen i studiet.

Dette karakteriseres ved en konkret, verkstedsbasert utprøving av materialer og prosesser knyttet til utvikling av produkter for et bærekraftig miljø. Her spiller også den sansemessige erfaringen en grunnleggende rolle. Produktdesign er et fagområde med vekt på både tradisjoner og historie, brukerorientering og funksjonalitet knyttet opp mot nåtid, etterspørsel i markedet, bærekraftighet og trender.

(OsloMet, 2020c) ${ }^{1}$

Uteksaminerte studenter jobber i offentlig eller privat sektor, ofte i egen bedrift. Noen tar videreutdanning, for eksempel i Praktisk pedagogisk utdanning (PPU) eller fordyper seg på masternivå. Forbruk og gjenbruk er sentralt i utdanningen.

\section{Faglærerutdanning i design, kunst og håndverk}

Ved Institutt for estetiske fag (EST) utdannes det hvert år om lag 60 faglærere i design, kunst og håndverk. Dette er en spesialisert lærerutdanning som kvalifiserer for undervisning i faget Kunst og håndverk fra 1-10 trinn i grunnskolen og for designrelaterte studieprogram i den videregående opplæringen. Faglærerutdanningen er treårig og reguleres av nasjonal Forskrift om rammeplan for treårige faglærerutdanninger i praktiske og estetiske fag (Kunnskapsdepartementet, 2013). I tillegg til de nasjonale rammeplanene er faglærerutdanningen også styrt av retningslinjer for de utdanninger de skal utdanne lærere til gjennom vekslende læreplaner (Opplæringsloven, 1998; Kirke-, utdannings- og forskningsdepartementet, 1994; Kunnskapsdepartementet, 2006).

Styringsdokumentene for lærerutdanningene i Norge har innvirkning på studienes utforming som igjen har innvirkning på hva som til enhver tid vektlegges i den norske skolen. Grunnskolen er selve fundamentet i allmenndannelsen som alle barn tar del i. Derfor pågår det en stadig diskusjon om hva som skal vektlegges. I den spesialiserte Faglærerutdanningen i design, kunst og håndverk blir bærekraft blant annet knyttet til kvalitet, materialitet og holdbarhet. Forbruk og bruk av ressurser blir også knyttet til visuell kommunikasjon.

\section{Energi og miljø i bygg}

Ved bachelorprogrammet Energi og miljø i bygg utdannes det om lag 50 kandidater i året. Det er Institutt for bygg- og energiteknikk som tilbyr programmet. Programmets eksistensberettigelse ligger i å bidra til bærekraftig utvikling med spesielt fokus på bygg i en verden med klimapåvirkning og knappe ressurser. Kandidatene som uteksamineres fra programmet skal bidra til energioptimale bygg som er gode å være i.

Utdanningen er rammeplanstyrt, som alle andre ingeniørutdanninger ved TKD. Det betyr at det stilles krav til emnesammensetning og innhold i emnene. Grunnleggende og klassiske emner innen matematikk, fysikk og kjemi er selvskrevne. Likeledes er det krav til emner og innhold innen programmering, фkonomi og statistikk. Innenfor rammene satt av rammeplanen må fagmiljøet finne plass til sin spesialisering. Navnet til studieprogrammet gir en berettiget forventning om at bærekraftsperspektivet er ivaretatt gjennom hele studiet.

\section{Maskiningeniør, Elektronikkingeniør, Bioteknologi- og kjemiingeniør}

Institutt for Maskin, Elektronikk og Kjemi (MEK) tilbyr tre forskjellige rammeplanstyrte bachelorstudier: Maskiningeniør, Elektronikkingeniør, og Bioteknologi- og kjemiingeniør. Til sammen utdannes det 200 studenter ved disse programmene per år.

Maskiningeniørutdanningen er klassisk og generell med fokus på utvikling og drift av mekaniske komponenter og teknisk utstyr. Elektronikkingeniørene utdannes for å jobbe med løsninger innen auto- 
masjon i en verden som har nesten 200 milliarder enheter koblet til internett. Bioteknologi- og kjemiingeniørene har en høyere grad av spesialisering mot forskning og industrianvendelser innen medisin, farmasi, miljø og næringsmidler. Historisk sett har det vært mindre overlapp mellom disse utdanningene, men instituttet fokuserer i dag på $\varnothing$ kt deling av ressurser ved å utvikle hybride studieprogrammer.

I tillegg tilbyr instituttet et 60 stp. program for Kompletterende ingeniør-og teknologiutdanning med varighet på ett år (OsloMet, 2019e). Dette samfunnsrelevante programmet tar imot flyktninger med utdanning som ingeniør eller teknolog, og hjelper dem å oppnå den nødvendige kulturelle kompetansen for å bli mer attraktive på det norske arbeidsmarkedet.

\section{BAEREKRAFT I PROGRAMPLANENE}

Programplanene med de tilhørende læringsutbyttebeskrivelsene har blitt gjennomgått for å unders $\emptyset$ ke hvorvidt de fire STAUNCH områdene 1) økonomisk perspektiv, 2) miljøperspektiv, 3) sosialt perspektiv og 4) 'Cross-cutting themes' nevnes, beskrives eller diskuteres.

\section{$\varnothing$ konomisk perspektiv}

Analyseverktøyet STAUNCH har følgende kategorier under økonomi: «GNP productivity; Resource use, exhaustion (materials, energy, water); Finances and SD; Production, consumption patterns; Developmental economics» (Lozano \& Young, 2013, p. 135). Dette er svært konkrete kategorier som bare i liten grad er synlig i de studerte planene. Vi har derfor også søkt formuleringer i mer overordnede planer som grunnlag for å analysere tilstedeværelsen av en økonomisk dimensjon i studiene.

En emnebeskrivelse for Produktdesign er Produktutvikling; estetikk og marked, og der er generell kompetanse beskrevet slik i forhold til økonomi: «Studenten kan reflektere over hvordan helse, miljø og omgivelser (HMS) i faget bidrar til bærekraftig praksis» (OsloMet, 2020c). Videre i emnebeskrivelsen for Dynamisk prosjektledelse (10 stp.) er kunnskap beskrevet som at: «Studenten kjenner til metoder for konseptutvikling, nyskapning og innovasjon» (OsloMet, 2020c). Generell kompetanse er beskrevet som at: «Studenten kan bidra til bærekraftige designløsninger og lede innovasjonsprosesser innen design» (OsloMet, 2020c).

Det $\varnothing$ konomiske perspektiv i Faglærerutdanning i design, kunst og håndverk er indirekte synlig som et dannelsesperspektiv i lærerutdanningen og i de nasjonale retningslinjene for grunnskolen. Læreplanen for grunnskolen har status som en forskrift og der står det blant annet for ungdomstrinnet at «... målet for opplæringen er at elevene skal kunne skape klær og drøfte mote, pris og kvalitet i et forbrukerperspektiv» (Kunnskapsdepartementet 2006, s. 134). Overordnet denne formuleringen er opplæringsloven og den generelle delen av læreplanen for grunnskolen der det står:

\footnotetext{
Verdenskommisjonen for miljø og utvikling har pekt på de problemer som ligger i sammenflettede kriser - f.eks. i bedret helse og økningen av verdens befolkning; i moderne teknologi med overforbruk av ressurser og skade på liv; i økonomisk vekst som forurenser og ødelegger naturen; i fattigdom og forarming. Samspillet mellom økonomi, økologi og teknologi stiller vår tid overfor særlige kunnskapsmessige og moralske utfordringer for å sikre en bærekraftig utvikling. [...] Konkret viten er nødvendig, men er alene ikke nok - helhetlig naturfaglig og økologisk kunnskap er også nødvendig. I undervisningen må den knyttes til samfunnsfaglig innsikt i økonomi og politikk, og til etisk orientering. Elevene må lære å se ting i sammenheng og bevare overblikk - lære å skue framover i livet og utover i verden. (Kirke-, utdanningsog forskningsdepartementet, 1994, s. 21)
}

På denne måten bærer grunnutdanningens overordnede dannelsesprosjekt i seg et $\varnothing$ konomisk aspekt. Dette aspektet gjelder dermed også lærerutdanningen, men økonomi er ikke eksplisitt nevnt i lærerutdanningens rammeplaner.

$\varnothing$ konomiske perspektiver på bærekraft er i liten grad synlige i programplanene for Energi og miljø i bygg. Emner som adresserer bærekraft knyttet til фkonomi er i mindretall, men de eksisterer. Energipriser er del av læringsutbyttebeskrivelsene for emnet Bygningssimulering. Energimerking av bygg vies også oppmerksomhet. Disse temaene har både en miljøside og en økonomisk side. Koblingen 
mellom de to perspektivene er det essensielle i dette emnet, eller som det står i emnebeskrivelsen: «Studenten kan jobbe tverrfaglig for å prosjektere optimale løsninger med hensyn til inneklima, energikostnader, og miljømål» (OsloMet, 2020b). Økonomi er videre koblet til prosjektledelse gjennom emnet Prosjektledelse og økonomi. Livssykluskostnader, grunnleggende $\varnothing$ konomisk begrepsforståelse, standarder for kalkulasjon av bygge- og anleggsarbeider, prosjektkontrakter og rolleforståelse er andre tema som omhandles i beskrivelsen og som er relevante for kategoriene i STAUNCH.

$\varnothing$ konomiperspektivet i studiet for Maskiningeniør, Elektronikkingeniør, Bioteknologi- og kjemiingeniør er heller ikke veldig tydelig, men til gjengjeld har emnet Teknologiledelse til hensikt å styrke studentenes evne til å bidra til å lede verdiskaping i organisasjoner. Som en del av dette, må studentene kunne forklare og forstå bedrifts $\varnothing$ konomiens hovedelementer, foreta lønnsomhetsvurderinger, vurdere $\varnothing$ konomisk risiko, og utarbeide en forretningsplan. Økonomi er ellers ikke noe som nevnes direkte i programmet, men som blir implisert fra effektivitetsberegninger i fag som Hydraulikk og maskinsystemer hvor man optimaliserer hydrauliske kretser og finner løsninger med lavest energiforbruk; eller i faget Mekanisk konstruksjon og teknisk design hvor man utfører levetidsberegninger av maskindeler. I denne sammenhengen er det vanskelig å koble de økonomiske og miljømessige perspektivene fra hverandre siden begge har til hensikt å redusere ressursforbruk.

\section{Miljøperspektiv}

Analyseverktøyet STAUNCH har følgende kategorier under miljø: «Policy/administration; Products and services (inc. transport); Pollution/accumulation of toxic waste/effluents; Biodiversity; Resource efficiency and eco-efficiency; Global warming, emissions, acid rain, climate change, ozone depletion; Resources (depletion, conservation) (materials, energy, water); Desertification, deforestation, land use; Ozone depletion; Alternatives» (Lozano \& Young, 2013, p. 135). Vi kan dele de måtene miljøperspektivet er tilstede i TKD sine utdanninger inn i to hovedkategorier. Den første, som kjennetegner både faglærerutdanning og produktdesign, understreker refleksjon og en kvalitativ overordnet forståelse av sammenhengene mellom de forskjellige disiplinene. Dette konkretiseres fortrinnsvis gjennom kritiske refleksjoner om gjenbruk, materialvalg og fornuftig bruk generelt. Den andre hovedtilnærmingen til bærekraft er tydelig eksemplifisert i ingeniørutdanningene, hvor fokuset går vekk fra det humanistiske og samfunnsvitenskapelige og mot bruk av teknikker basert på realfagvitenskap. Omfang og kobling på tvers av disipliner blir til en viss grad redusert, men til gjengjeld blir tolkningen entydig og lettere å systematisere. Alt i alt er miljø- og bærekraftsperspektivet tydelig artikulert i læringsutbyttebeskrivelsene.

Bærekraft er i produktdesignstudiet integrert i emnet Kritisk refleksjon i designpraksis (10 stp.), der læringsutbytte blant annet er at «Studenten skal kunne gjennomføre en kompleks designprosess med tilhørende designfaglig fordypning i et internasjonalt og bærekraftig perspektiv» (OsloMet, 2020). Bærekraftdimensjonen innen teknologi handler videre om HMS, materialbruk og sikkerhet, gjenbruk og trygg anvendelse av materialer (Haugen, 2019; Thompson, 2007).

All lærerutdanning i Norge er regulert av overordnede mål og retningslinjer som skal gjennomsyre utviklingen av konkrete planer og praksis. I faglærerutdanningen er et bærekraftig miljøperspektiv tydelig artikulert i opplæringsloven (1998) og i læreplanenes generelle del (1994), der det miljøbevisste mennesket beskrives som en av sju menneskelige egenskaper som skoleverket skal fremme. Der står det:

Vårt levesett og vår samfunnsform har dype og truende virkninger for miljøet. Dette driver fram konflikter mellom grupper og mellom land. Konsekvensene av vitenskapens anvendelse er på en gang blitt mer omfattende og sammenflettede. Dette gjør det nødvendig å utvide innsikten om sammenhenger på tvers av faggrenser, og å mobilisere til innsats på tvers av landegrenser. Det $\varnothing$ ker kravene både til viten og til bevisste $\varnothing$ kologiske, etiske og politiske avgjørelser hos enkeltindivider og samfunn. Forståelse gjør at valg kan treffes med innsikt, etisk fostring at de kan tas med skjønn. De utviklede land med høyt utdanningsnivå har et særlig ansvar for å sikre verdens felles framtid. (Kirke-, utdannings- og forskningsdepartementet, 1994, s. 20-21) 
Et bærekraftig miljøperspektiv er også tydelig integrert i det bærende emnet Design, kunst og håndverk (DKH) (105 stp.) i faglærerutdanningen. Dette kommer til uttrykk gjennom læreutbyttebeskrivelser som: «Studenten har grunnleggende kunnskap om gjenbruk og bærekraftig perspektiv» (1. år). I det andre og tredje studieåret utvikles bærekraftsperspektivet gjennom læringsutbyttebeskrivelser som: «Studenten kan vurdere sammenhenger mellom materialer, helse og ressursbruk i et økologisk perspektiv» (2. år) og «Studenten har kunnskap om konsum, bærekraft og miljøproblematikk i fagområdet» (3. år) (OsloMet, 2019d). Emnet Profesjonsfag (45 stp.) inkluderer både fagdidaktikk og pedagogikk. I læringsutbyttebeskrivelsene er bærekraft tydelig beskrevet, spesielt som tiltak innen HMS. I første års læringsutbyttebeskrivelser står det: «Studenten har kunnskap om fagfeltets bredde og utvikling av bærekraftige holdninger til materiell og visuell kultur i et tverrfaglig perspektiv». I det tredje studieåret er bærekraftsperspektivet formulert på følgende måte: «Studenten kan reflektere over og drøfte konsum, bærekraft og miljøproblematikk i et fagdidaktisk perspektiv» (OsloMet, 2019d).

Fakultetets ingeniørutdanninger, med unntak av Energi og miljø i bygg, drøfter i mindre grad miljøgestalten, men zoomer i stedet inn på noen målbare aspekter av miljøkvaliteten. I mange tilfeller er miljøperspektivet økonomisk motivert. Et eksempel på dette er i emnet Termodynamikk, som tar opp optimalisering av energiproduksjon og effektivisering av energiforbruk. Andre emner uttaler intensjonen om å ta vare på miljøaspektet uten å spesifisere hvordan dette konkretiseres i praksis. Dette kommer til uttrykk i emnet Materialteknologi, hvor det står at studentene "har innsikt i miljømessige, helsemessige, samfunnsmessige og $\varnothing$ konomiske konsekvenser av materialvalg og kan sette disse i et etisk perspektiv og et livsløpsperspektiv» (OsloMet, 2019f).

Ingeniørstudiet Energi og miljø i bygg har bærekraft som et gjennomgående tema, selv om ordet bærekraft ikke nødvendigvis brukes i mange av emnebeskrivelsene. Ikke overraskende er det spesielt miljødimensjonen av bærekraft som vektlegges i beskrivelsene. Energieffektivitet er et gjennomgående tema, det vil si hvordan man kan unngå å konvertere høyverdige energiformer til lavverdige energiformer. Dette behandles både i et teoretisk perspektiv, for eksempel i emnet Termodynamikk, hvor det er naturlovene som er i fokus, og i et anvendt perspektiv, for eksempel i emnet Varme, Ventilasjon og Sanitærteknikk, hvor det samme temaet står sentralt ved prosjektering av teknisk gode Iøsninger for bygg. Lover og standarder er også en integrert del av dette arbeidet og er tydelig representert i emnebeskrivelsene. Både det ytre miljøet og innemiljøet er del av utdanningen. Som studieprogramnavnet bebuder, er hovedfokuset på energi og miljø i bygg. Slik utdanningen er bygget opp kommer innemiljøet tydeligere utover i studieløpet. I de første semestrene inkluderes bærekrafttema som global oppvarming, materialbruk, ozonnedbrytning, giftstoffer og fornybar energi. Disse temaene inngår i klassiske emner som undervises i ingeniørutdanninger over hele verden, men emneansvarlig har særlig vektlagt problemstillinger som er relevante for miljødimensjonen av bærekraft. Formuleringene i emnebeskrivelsene må likevel kunne beskrives som 'runde', eksempelvis «Studenten kan beskrive miljøaspekter» og «Studenten kjenner til livsløpsvurderinger og miljømerker» (OsloMet, 2020b).

\section{Sosialt perspektiv}

Det sosiale perspektivet på bærekraft i STAUNCH-systemet er karakterisert med følgende stikkord: «Demography, population; Employment, unemployment; Poverty; Bribery, corruption; Equity, justice; Health; Social cohesion; Education; Diversity; Cultural diversity (own and others); Labour, human rights» (Lozano \& Young, 2013, p. 135). Samlet sett inneholder disse stikkordene sider ved det som vi med ett ord kan benevne som velferd. Profesjonsutdanningene berører de sosiale aspektene ved bærekraft som en slags implisitt kontekst med forankring på et overordnet nivå. De er derfor ikke nødvendigvis eksplisitt uttalt i programplanene for profesjonsutdanningene av designere, lærere og ingeniører. Det betyr imidlertid ikke at de er fraværende. I OsloMet sin overordnede Strategi 2024 er velferd fremhevet på denne måten: «Strategi 2024 legger vekt på at OsloMet skal være en av landets ledende på forskningsbasert kunnskap for velferdssamfunnet» (Høgskolen i Oslo og Akershus, 2017). Denne strategien (vedtatt nivå) skal styre all utdanning ved OsloMet, men kommer ulikt til uttrykk i programplanene for designere, lærere og ingeniører.

I programplanen for Produktdesign finner vi følgende uttalte ferdighet i emnet Designhistorie og designteori (10 stp.): «Studenten kan vise perspektivdannelse og anvende analyse og kritisk reflek- 
sjon med utgangspunkt i eget kjennskap til designs betydning og rolle for en bærekraftig samfunnsutvikling» (OsloMet, 2020c). I emnet Kulturforståelse og kommunikasjon (10 stp.) introduseres også bærekraft som del av en helhet:

Emnet skal gi generell kulturforståelse gjennom å forholde seg til gjenstander som kulturelle uttrykk, samt se prosjektet i en kulturell kontekst og i et samfunnsperspektiv. Emnet inneholder fagstoff om etnografi, kartlegging, bærekraft, utforming av presentasjonsmateriell og kommunikasjon. (OsloMet, 2020c)

Videre skal studentene «kjenne til problemstillinger, prosesser, verktøy og metoder innen kulturforståelse, kommunikasjon og presentasjon, herunder aktuelle teorier som; semiotikk, design etnografi, emosjonell design og bærekraftig design». En viktig ferdighet er at «studenten kan reflektere rundt bærekraft i sin designprosess» (OsloMet, 2020c).

Utdanning er et eget stikkord i STAUNCH-systemet. Antakelig forstått som at utdanning fremmer flere av de andre punktene som for eksempel employment, fravær av poverty, health, social cohesion, diversity and human rights. I et slikt perspektiv tar Faglærerutdanningen i design, kunst og håndverk med emnet Profesjonsfag opp i seg mange av disse aspektene. Det sosiale perspektivet ligger som en bærebjelke i all lærerutdanning. Lærerne utdannes for å undervise i den obligatoriske grunnskolen som er den sosiale og kulturelle basisen for det felleskapet som et samfunn er så avhengig av. Det sosiale er allikevel ikke så eksplisitt uttrykt verken i opplæringsloven (1998) eller i planene til faglærerutdanningen. Det sosiale ligger mer eller mindre innbakt i dannelse, etikk, samarbeid og HMS.

I faglærerutdanningen kommer dette til uttrykk i formuleringer som: «Studenten har kunnskap om fagfeltets bredde og utvikling av bærekraftige holdninger til materiell og visuell kultur i et tverrfaglig perspektiv» (OsloMet, 2019d, Profesjonsfag, 1. år). Samfunnsperspektivet på bærekraft uttrykkes eksplisitt i studiets andre år: «Studenten har kunnskap om fagfeltets potensiale for utvikling av bærekraftige holdninger i et samfunnsetisk perspektiv» (OsloMet, 2019d, Profesjonsfag, 2. år). Medmenneskelighet og solidaritet knyttes også til bærekraft og uttrykkes på følgende måte i grunnskolens overordnede generelle del: «Og i en bærekraftig utvikling må etisk fostring til medmenneskelighet og solidaritet med verdens fattige være et bærende prinsipp» (Kirke-, utdannings- og forskningsdepartementet, 1994, s. 21)

Det fokuseres lite på sosiale perspektiver av bærekraft i studieprogrammet Energi og miljø $i$ bygg. Helse er et unntak i så måte, og studentene skal «kunne gjøre rede for sammenhengen mellom inneklima og sykdom og helse» (OsloMet, 2020b). Konkrete utfordringer som påvirker helse nevnes, som for eksempel mikro-organismer, muggsopp og legionellavekst. Demografi og byutvikling er et underliggende tema i flere av emnene, uten at det i særlig grad gjøres eksplisitt i læringsutbyttebeskrivelsene. Det inkluderes i studieprogrammet gjennom arbeidet med planlegging og gjennomføring av byggeprosjekter.

I ingeniørutdanningene Maskiningeniør, Elektronikkingeniør, Bioteknologi- og kjemiingeniør kunne det sosiale aspektet ved bærekraft egne seg for drøftinger i emnene Hydraulikk og maskinsystemer og Statistikk og risikoanalyse, men dette er ikke spesifikt nevnt i læringsutbyttebeskrivelsen. De praktiske anvendelsene som presenteres er heller valgt etter det som menes kan eksemplifisere teorien i faget på best mulig måte.

Alle de nevnte profesjonsutdanningene bidrar med kompetanse som er av avgjørende betydning for utvikling av velferd i et bærekraftsperspektiv. Det er innlysende at kalkulasjoner som ligger til grunn for å bygge trygge veier og broer er viktige for å koble små lokale samfunn til fellesskapets velferdsgoder for helse. Men det er kanskje ikke så innlysende at det er implisitt og dermed heller ikke $n \emptyset$ dvendig å bli formulert i programplanen. Det hadde vært en fordel dersom disse profesjonsutdanningenes bidrag til OsloMets store overordnede velferdsprosjekt hadde kommet tydeligere frem i programplanene.

\section{Cross-cutting themes}

Under kategorien 'cross-cutting themes' finner vi følgende emner: "People as part of nature/limits to growth; Systems thinking/application; Responsibility; Governance; Holistic thinking; Long term thinking; 
Communication/Reporting; SD statement; Disciplinarity; Ethics/philosophy" (Lozano \& Young, 2013, p. 135). I motsetning til de $\varnothing v r i g e$ tre kategoriene, er det ikke åpenbart om, og eventuelt hvordan, utdanningene skiller seg fra hverandre. Tabell 1 nedenfor inneholder overordnende læringsutbytter for de programmene som gjennomgås i denne artikkelen. De er her sortert etter områdene i STAUNCHsystemet, for å synliggjøre likheter og forskjeller.

Tabell 1. Sitatene er hentet fra programplanene for Produktdesign (OsloMet, 2020c), Faglærer i design, kunst og håndverk (OsloMet, 2019d), Maskiningeniør (OsloMet, 2019f) og Energi og Miljø i Bygg (OsloMet, 2020b).

\begin{tabular}{|c|c|c|c|c|}
\hline 'Cross-cutting themes' & Produktdesign & Faglærer-utdanningen & Maskiningeniør & E\&M-ingeniør \\
\hline Helhetstekning & $\begin{array}{l}\text { Studenten kan sette } \\
\text { design inn i et bærekraftig } \\
\text { og globalt } \\
\text { samfunnsperspektiv og } \\
\text { kan bruke } \\
\text { innovasjonsteknikker. }\end{array}$ & $\begin{array}{l}\text { Kandidaten kan legge til } \\
\text { rette for kreative } \\
\text { prosesser, estetisk } \\
\text { opplevelse, erfaring og } \\
\text { erkjennelse og } \\
\text { nyttiggjøre seg av lokalt } \\
\text { arbeids-, kultur- og } \\
\text { samfunnsliv i elevenes } \\
\text { læring. }\end{array}$ & & $\begin{array}{l}\text { Kandidaten har } \\
\text { kunnskap som gir et } \\
\text { helhetlig perspektiv på } \\
\text { energi- og } \\
\text { miljøingeniørens } \\
\text { fagområde. }\end{array}$ \\
\hline Langtidstenkning & $\begin{array}{l}\text { Gjennom research i } \\
\text { markedet og brukerdrevet } \\
\text { designprosess, skal } \\
\text { studenten ta frem et } \\
\text { estetisk og kommersielt } \\
\text { produkt, konsept eller en } \\
\text { tjeneste og definere på } \\
\text { hvilken måte sin løsning } \\
\text { eller konsept kan forandre } \\
\text { vår fremtid i et samfunn } \\
\text { med stort fokus på } \\
\text { bærekraft. }\end{array}$ & & & \\
\hline Systemtenkning & $\begin{array}{l}\text { Studenten kan } \\
\text { kontekstualisere sitt virke } \\
\text { som designer og forstår } \\
\text { hvordan dette bidrar i } \\
\text { samfunns- og } \\
\text { bærekraftperspektiv. }\end{array}$ & & $\begin{array}{l}\text { Kandidaten har } \\
\text { grunnleggende } \\
\text { kunnskaper om } \\
\text { konstruksjon og/eller } \\
\text { produksjon, materialer } \\
\text { og kunnskap innen } \\
\text { helhetlig system- og } \\
\text { produktutvikling. } \\
\text { Kandidaten har } \\
\text { kunnskap som bidrar til } \\
\text { relevant spesialisering, } \\
\text { bredde eller dybde. }\end{array}$ & $\begin{array}{l}\text { Kandidaten har bred } \\
\text { kunnskap som gir et } \\
\text { helhetlig } \\
\text { systemperspektiv på } \\
\text { ingeniørfaget generelt, } \\
\text { med fordypning i tema } \\
\text { relatert til } \\
\text { energisystemer og } \\
\text { miljøproblematikk i } \\
\text { bygg. }\end{array}$ \\
\hline \multirow[t]{3}{*}{ Etikk } & \multirow{3}{*}{$\begin{array}{l}\text { Studenten har forståelse } \\
\text { for, og praktisk erfaring i å } \\
\text { håndtere samspillet } \\
\text { mellom bruker, miljø og } \\
\text { produkt i en } \\
\text { designprosess og kan } \\
\text { beskrive og diskutere } \\
\text { etiske utfordringer i møte } \\
\text { mellom design, teknologi } \\
\text { og samfunn. Studenten } \\
\text { har forståelse for og } \\
\text { praktisk erfaring innen } \\
\text { tema om integrering, } \\
\text { medvirkning og } \\
\text { flerkulturelle perspektiver. }\end{array}$} & $\begin{array}{l}\text { Kandidaten kan fremme } \\
\text { bærekraftig utvikling i et } \\
\text { samfunnsetisk } \\
\text { perspektiv og stimulere } \\
\text { til forståelse av } \\
\text { demokrati, demokratisk } \\
\text { deltakelse og treffe } \\
\text { begrunnede verdivalg. }\end{array}$ & \multirow{3}{*}{$\begin{array}{l}\text { Kandidaten har innsikt i } \\
\text { miljømessige, } \\
\text { helsemessige, } \\
\text { samfunnsmessige og } \\
\varnothing \text { konomiske } \\
\text { konsekvenser av } \\
\text { produkter og løsninger } \\
\text { innenfor sitt fagområde } \\
\text { og kan sette disse i et } \\
\text { etisk perspektiv og et } \\
\text { livsløpsperspektiv. }\end{array}$} & \multirow{3}{*}{$\begin{array}{l}\text { Kandidaten } \\
\text { kjenner til den } \\
\text { teknologiske utviklingen } \\
\text { innen fagområdet } \\
\text { energi og miljø i bygg, } \\
\text { ingeniørens rolle i } \\
\text { samfunnet og har } \\
\text { kunnskap om } \\
\text { samfunnsmessige, } \\
\text { miljømessige, etiske og } \\
\varnothing \text { konomiske } \\
\text { konsekvenser av } \\
\text { teknologi. }\end{array}$} \\
\hline & & $\begin{array}{l}\text { Kandidaten har } \\
\text { kunnskap om relevante } \\
\text { profesjonsetiske } \\
\text { problemstillinger. }\end{array}$ & & \\
\hline & & $\begin{array}{l}\text { Kandidaten kan bruke } \\
\text { digitale medier som } \\
\text { verkt } \varnothing y, \text { læringsarena, } \\
\text { formidling av fagstoff og } \\
\text { har et bevisst forhold til } \\
\text { personvern og etisk bruk } \\
\text { av internett. }\end{array}$ & & \\
\hline
\end{tabular}




\begin{tabular}{|c|c|c|c|c|}
\hline \multirow[t]{2}{*}{ Bærekraft-ambisjon } & $\begin{array}{l}\text { Studenten kjenner til teori } \\
\text { og prinsipper for } \\
\text { bærekraftig design og kan } \\
\text { anvende denne. }\end{array}$ & $\begin{array}{l}\text { Kandidaten har } \\
\text { kunnskap om } \\
\text { sammenhenger mellom } \\
\text { materiale, helse og } \\
\text { ressursbruk i et } \\
\text { økologisk og bærekraftig } \\
\text { perspektiv. }\end{array}$ & & \multirow[t]{2}{*}{$\begin{array}{l}\text { Kandidaten er bevisst } \\
\text { miljømessige, etiske og } \\
\varnothing \text { konomiske } \\
\text { konsekvenser ved } \\
\text { analyser og prosesser } \\
\text { som angår energi og } \\
\text { innemiljø i bygg. }\end{array}$} \\
\hline & $\begin{array}{l}\text { Studenten har forståelse } \\
\text { for samfunnets behov for } \\
\text { bærekraftig design. }\end{array}$ & $\begin{array}{l}\text { Kandidaten kan utnytte } \\
\text { fagets muligheter til å } \\
\text { fremme bærekraftig } \\
\text { utvikling i et } \\
\text { samfunnsetisk } \\
\text { perspektiv og stimulere } \\
\text { til forståelse av } \\
\text { demokrati, demokratisk } \\
\text { deltakelse og treffe } \\
\text { begrunnede verdivalg. }\end{array}$ & & \\
\hline \multirow[t]{2}{*}{ Kommunikasjon } & \multirow{2}{*}{$\begin{array}{l}\text { Studenten kjenner } \\
\text { til problemstillinger, } \\
\text { prosesser, verktøy og } \\
\text { metoder innen } \\
\text { kulturforståelse, } \\
\text { kommunikasjon og } \\
\text { presentasjon, herunder } \\
\text { aktuelle teorier som; } \\
\text { semiotikk, design } \\
\text { etnografi, emosjonell } \\
\text { design og bærekraftig } \\
\text { design. }\end{array}$} & $\begin{array}{l}\text { Kandidaten kan bruke } \\
\text { digitale medier i } \\
\text { skapende arbeid, } \\
\text { formidling og } \\
\text { kommunikasjon } \\
\text { innenfor etiske } \\
\text { retningslinjer relatert til } \\
\text { skole og samfunn. }\end{array}$ & $\begin{array}{l}\text { Kandidaten kan finne, } \\
\text { vurdere og utnytte } \\
\text { teknisk viten på en } \\
\text { kritisk måte innen sitt } \\
\text { område, og fremstille } \\
\text { dette slik at det belyser } \\
\text { en problemstilling, både } \\
\text { skriftlig og muntlig. }\end{array}$ & \multirow[t]{2}{*}{$\begin{array}{l}\text { Kandidaten kan formidle } \\
\text { kunnskap til ulike } \\
\text { målgrupper både } \\
\text { skriftlig og muntlig og } \\
\text { evner å synliggjøre } \\
\text { teknologiens betydning } \\
\text { og konsekvenser i } \\
\text { samfunnet. }\end{array}$} \\
\hline & & $\begin{array}{l}\text { Kandidaten har } \\
\text { kommunikasjons- og } \\
\text { relasjonskompetanse og } \\
\text { kan bruke relevant } \\
\text { fagterminologi i skriftlig } \\
\text { og muntlig } \\
\text { kommunikasjon med } \\
\text { ulike målgrupper. }\end{array}$ & $\begin{array}{l}\text { Kandidaten kan formidle } \\
\text { ingeniørfaglig kunnskap } \\
\text { til ulike målgrupper } \\
\text { både skriftlig og muntlig } \\
\text { og kan bidra til å } \\
\text { synliggjøre teknologiens } \\
\text { betydning og } \\
\text { konsekvenser. }\end{array}$ & \\
\hline Filosofi & & & & \\
\hline
\end{tabular}

Alle studieprogrammene har integrert bærekraftsfokus i de respektive fagfeltene, også for temaene aktuelle i den generiske 'cross-cutting themes'-kategorien, slik det fremgår i tabell 1. Det fremstår naturlig og riktig at studieprogrammene adresserer relevante, aktuelle og fremtidige bærekraftsutfordringer for profesjonsutøverne de utdanner. Alle temaene i STAUNCH-kategorien 'cross-cutting themes' er tungt inne i de overordnede planene for Faglærerutdanningen i design, kunst og håndverk. Det samme gjelder også for de rammeplanstyrte ingeniørutdanningene.

Kommunikasjon generelt og ferdigheter som å kommunisere presist om eget fagfelt, muntlig og skriftlig, omhandles i rikt monn både i rammeplanene (faglærer- og ingeniørutdanningene), i overordnende læringsutbyttebeskrivelser og i emnebeskrivelsene. Ved alle studieprogrammene i denne studien vektlegges kommunikasjon høyt som en viktig generisk ferdighet. I flere emner i flere utdanninger skal studentene gi tilbakemelding på hverandres utkast og utvikle kompetanse i å gi tilbakemeldinger. Med en tanke om livslang læring i bakhodet, fremstår det som en god investering i kandidatenes fremtid. Spesielt for denne kategorien er at også de rent disiplinbaserte emnene, eksempelvis matematikk og fysikk i ingeniørutdanningen, bidrar til bærekraftsperspektivet.

Det er vanskelig å skille tydelig mellom helhets-, langtids- og systemperspektiv slik de overordnede læringsutbyttebeskrivelsene er formulert, og det er vel heller ikke noe mål i seg selv. De to ingeniørutdanningene vektlegger systemperspektivet i sine respektive fagfelt tydeligere enn faglærerutdanningen, trolig fordi systemtenkning tradisjonelt er anerkjent som viktig i ingeniørutdanning. Det betyr imidlertid ikke at lærerutdanning ikke vektlegger systemtenkning, men det gjøres på en litt annen måte. Utdanning er i seg selv et system der ulike utdanningspolitiske mål (ideologisk nivå) skal flettes inn i program- og emneplaner (vedtatt læreplan) som igjen skal implementeres i den konkrete under- 
visningspraksis (gjennomført nivå) og følge en viss progresjon som skal støtte opp om studenters og elevers læring (erfart nivå). Systemtenkning i et helhetsperspektiv er også til stede i produktdesignutdanningen, som systemtenkning i tjenestedesign og for eksempel i emnet Kulturforståelse og kommunikasjon (10 stp.) hvor bærekraft introduseres som del av en helhet:

Emnet skal gi generell kulturforståelse gjennom å forholde seg til gjenstander som kulturelle uttrykk, samt se prosjektet i en kulturell kontekst og i et samfunnsperspektiv. Emnet inneholder fagstoff om etnografi, kartlegging, bærekraft, utforming av presentasjonsmateriell og kommunikasjon. (OsloMet, 2020c)

Samfunnsutvikling, og gjerne en bærekraftig samfunnsutvikling, er et felles anliggende ved alle de unders $\emptyset$ kte studieprogrammene. Kanskje tydeligst artikulert på emnenivå i produktdesignutdanningen, for eksempel i emnebeskrivelsen for Designhistorie og designteori (10 stp.): «Studenten kan vise perspektivdannelse og anvende analyse og kritisk refleksjon med utgangspunkt i eget kjennskap til designs betydning og rolle for en bærekraftig samfunnsutvikling» (OsloMet, 2020c).

Nødvendigheten av lagspill og tverrfaglig samarbeid (Sibbet, 2008) fremheves i produktdesignutdanningen gjennom prosjekter som gjentas årlig hvor studenter opplever både å være 'nyansatt' (1. år), seniordesigner (2. år) og leder (3. år). En liknende prosjektstrategi er også innarbeidet i ingeniørprogrammet Energi og miljø i bygg, hvor studentene allerede i første semester arbeider i team med ulike roller som minner om det som venter i fremtidig arbeidsliv. Nødvendigheten av tverrfaglig samarbeid understrekes også. Respekt for ulike roller og kompetanser i et samarbeid likeså.

Alle programmene har bacheloroppgave som en viktig og sentral del av det siste semesteret. Tema for bacheloroppgavene er ikke fastsatt på forhånd, men emnebeskrivelsene setter likevel krav til hva som skal inngå i en slik oppgave:

Bacheloroppgaven i Produktdesign går ut på å utforske, eksperimentere og utvikle et innovativt designprosjekt, samt vise sin forståelse og kompetanse innen design. Gjennom research i markedet og brukerdrevet designprosess, skal studenten ta frem et estetisk og kommersielt produkt, konsept eller en tjeneste og definere på hvilken måte sin løsning eller konsept kan forandre vår fremtid i et samfunn med stort fokus på bærekraft. Forprosjektet gir studenten innsikt i lederskap og innovasjon i forhold til design og designerens rolle i samfunnet. (OsloMet, 2020c)

Fagmiljøene ved alle de analyserte utdanningene har tydelig vektlagt bærekraftsfokus og generiske ferdigheter som støtter opp om et slikt fokus i emnebeskrivelsene for bacheloroppgavene. Et bærekraftsfokus inkluderer også et langtidsperspektiv i alle de analyserte utdanningene selv om dette ikke kommer tydelig frem emnebeskrivelsene og dermed $\mathrm{i}$ tabell 1.

Ingen av programplanene nevner filosofiske perspektiver i en slik grad at det nevnes i emnebeskrivelsene. For profesjonsutdanninger på bachelornivå er dette kanskje ikke oppsiktsvekkende. Filosofi står derfor uten innhold i tabell 1. Det betyr imidlertid ikke fravær av filosofisk begrunnede verdivalg i utdanningene. I faglærerutdanningens Profesjonsfag er for eksempel utdanningsfilosofi inkludert i både pedagogiske- og fagdidaktiske problemstillinger.

Valgemner benyttes i ulik grad i programmene som er unders $\varnothing$ kt i dette arbeidet. I rammeplan for ingeniørutdanning er det rom for valgemner på 30 studiepoeng. Blant valgemnene finnes det enkelte emner som utmerker seg med en tydelig bærekraftskomponent blant annet Teknologiledelse (tidligere omtalt) og Tverrfaglig prosjektarbeid. I sistnevnte emne er intensjonen å få studentene til å reflektere over systemer som favner flere disipliner samt oppmuntre og støtte at studentene utvikler kritisk sans og tar ansvar for eget prosjekt. Emnebeskrivelsen innleder med å oppmuntre til at prosjektene blir knyttet til bærekraft. Andre emner berører bærekraftstematikken på en tangentiell måte gjennom etiske vurderinger. For eksempel i emnet Introduksjon til kunstig intelligens der det står: "The student can reflect on the practical, social and ethical implications of the development of artificial intelligence» (OsloMet, 2019c) og i emnet Bioteknologi finner vi formuleringen: «studenten har et bevisst forhold til etiske konsekvenser av genteknologiske metoder i forbindelse med utvikling av genmanipulerte organismer, fosterdiagnostikk, rettsmedisinske analyser og DNA analyser i forbindelse med arvelige sykdommer» (OsloMet, 2019b). 


\section{NOEN LIKHETER OG ULIKHETER}

Vi har i denne unders $\varnothing$ kelsen tatt utgangspunkt i ett av Goodlads fem nivåer for didaktisk analyse: Vedtatt læreplan. Vi har analysert og drøftet vedtatte programplaner med tilhørende læringsutbyttebeskrivelser i lys av OsloMets overordnede strategi om å styrke bærekraft og velferd i utdanningstilbudene. For alle profesjonsutdanningene ligger FNs 17 bærekraftsmål som siktemål. De valgte utdanningene er omfattet av OsloMet sine strategiske mål, men samtidig inngår de ulike utdanningene i ulike faglige diskurser både formelt og ideologisk. Dette har igjen innvirkning på hvordan bærekraftsperspektivet implementeres i planer. Ingen av utdanningene har som sitt fremste mål å utdanne bærekraftseksperter. Det er likevel forventninger fra samfunnet, OsloMet og studentene selv at utdanningene integrerer bærekraftsperspektivet på en adekvat måte. I de analyserte planene er miljøperspektivet tydeligere artikulert enn det økonomiske og det sosiale perspektivet på bærekraft.

Ingeniør- og faglærerutdanning er styrt av nasjonale rammeplaner (Kunnskapsdepartementet, $2013,2018)$ med målsetting om å, i løpet av tre år, utdanne profesjonelle og relevante profesjonsutøvere. Produktdesign har ikke den samme type nasjonale rammeplaner, men alle profesjonsutdanningene utdanner for yrker der kompetanse knyttet til unike kontekster og løsningsprosesser må utvikles basert på lokale forhold og kreativ tenkning.

Tolkningen av strategier og nasjonale rammeplaner danner altså grunnlaget for utvikling og fastsettelse av læringsutbyttebeskrivelsene ved OsloMet. Den endelige programplanen vedtas på bakgrunn av pågående diskusjoner i fagmiljøet der tradisjoner og nye ideer brytes mot hverandre. En programplan utgjør det som fagmiljøet til enhver tid kan enes om uten for store splittelser og konflikter.

Bærekraft er, i bachelorutdanningene vi har unders $\varnothing$ kt, tydelig koblet til profesjonene og i noen grad begrenset til det som oppfattes som relevant for disse. Bachelorutdanningene skal utdanne dyktige

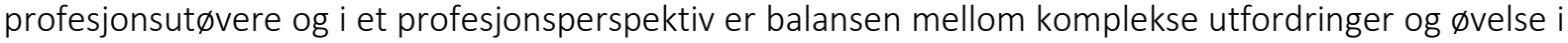
å beherske fagfeltets håndverk en utfordring.

Tradisjonene i design-, faglærer og ingeniørutdanningene eksisterer ikke uten grunn. Lærere med norsk lærerutdanning er trenet til å kunne se kompleksitet i en utdanningssituasjon. Denne kompleksiteten kan være knyttet til elevers og studenters forutsetninger og/eller knyttet til ulike fags egenart. I ingeniørutdanning er entydige - og gjerne kvantitative - vurderinger betraktet som den gylne standarden. Dette er en kraftfull metode med høy suksessrate. Entydige fakta med et relativt lavt kompleksitetsnivå gjør det enklere å sammenligne påstander - og løsninger - foreslått av flere individer. Produktdesignutdanningen har et noe tydeligere bærekraftsfokus enn de øvrige. Det kan være et resultat av et arbeid som pågikk høsten og vinteren 2019 og 2020. Hensikten var blant annet å profilere bærekraft fordi det motiverer både studenter og undervisere. Kollegiet og studentrepresentanter hadde over tid identifisert seks beslektede hovedområder ved studiet: Bærekraft, Kultur og samfunn, Innovasjon, Materialer \& Teknologi, Design Thinking og Kommunikasjon. Dette ble til slutt visualisert i en modell inspirert av den hermeneutisk spiral og viser en gradvis utvikling av forståelse gjennom gjentakende prosesser. I studiet blir de seks hovedområdene berørt og diskutert hvert studieår, slik at studentene stadig tilegner seg bredere og dypere kompetanse. De overordnende læringsutbyttebeskrivelsene for utdanningen ble tilsvarende justert. De emneansvarlige reviderte læringsutbyttebeskrivelsen for eget emne, med spesielt fokus på sammenhengen med de overordnede retningslinjene.

Prosessen er et eksempel på hvordan bærekraft kan bli integrert planmessig gjennom hele studieprogrammet. Bærekraft ble identifisert som ett av seks hovedområder, og gjennom det satt i relasjon til andre tema i studieprogrammet. Vi er usikre på om denne graden av kollektiv bevissthet om bærekrafts plass samt planer for 'tematisk progresjon' gjennom studieårene, er tilstede ved de øvrige utdanningene vi har unders $\varnothing \mathrm{kt}$, men dette er en måte å synliggjøre bærekraftens rolle i studieprogrammet.

\section{KONKLUSJON}

Vi har studert forholdet mellom OsloMets overordnede strategi om bærekraft og programplaner for profesjonsutdanningene for designere, lærere og ingeniører med tilhørende læringsutbyttebeskrivelser. Profesjonene designer, lærer og ingeniør fyller viktige funksjoner i utviklingen av samfunnet i 
bærekraftig retning. Bærekraft er synlig i alle disse profesjonsutdanningene på Fakultet for teknologi, kunst og design (TKD) på OsloMet. Vi har ikke kunnet påvise et stort gap mellom OsloMet sine strategier og de analyserte profesjonsutdanningene. Det betyr imidlertid ikke at programplanene er uten forbedringspotensiale. Med utgangspunkt i STAUNCH er miljøperspektivet tydeligere artikulert i programplanene enn det økonomiske- og det sosiale perspektivet på bærekraft.

Aller størst dokumentert fokus på bærekraft finner vi i utdanningen av designere på Institutt for produktdesign. Det er mest sannsynlig et resultat av den bevisste satsningen på bærekraft de har hatt det siste året. Vårt materiale viser at ingeniørutdanningene ikke har dokumentert tilsvarende fokus på bærekraft på bachelornivå (syklus 1). De grunnleggende beregningsferdighetene tar stor plass og er viktige for sertifiseringen som ingeniør. Sammenhengen med bærekraftsperspektivet gjøres ikke eksplisitt i program- og emneplaner, men er midlertidig 'på vent' til bacheloroppgaven og eventuelle masterstudier. Dette speiler en fagdidaktisk problematikk innen mange utdanninger, nemlig den mellom grunnleggende ferdigheter og overordnede refleksjoner. Utdanning av designere er ikke bundet av nasjonale rammeplaner og forskrifter slik utdanning av lærere og ingeniører er. I nasjonale retningslinjer for lærere er bærekraft tydelig artikulert.

De fleste utdanninger etterstreber en balanse mellom det ideologiske nivå og hvordan dette konkretiseres i vedtatte planer og gjennomført utdanning. Verken designeren, læreren eller ingeniøren kan opprettholde sin posisjon som autorisert profesjon for fremtiden uten at denne balansen stadig drøftes. Bærekraft i profesjonsutdanninger har avgjørende betydning for å kunne løse kommende samfunnsutfordringer på en etisk forsvarlig måte. Bærekraft vil i overskuelig fremtid være noe som pro-

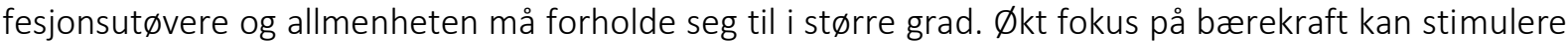
til å endre arbeids- og undervisningsformene i utdanninger, noe som i seg selv kan være positivt. Samtidig må man være forberedt på at det å utfordre lange tradisjoner og etablerte arbeidsmåter har potensial for å både komplisere og forsinke arbeidet. Bærekraft bør likevel vurderes aktivt i forhold til revidering og justering av programplaner fordi bevissthet om dette på tvers av fag og utdanninger, er av stor betydning for tverrfaglig samarbeid, for velferd og for en bærekraftig samfunnsutvikling. 


\section{LITTERATUR}

Cooper, T. (2005). Slower Consumption - Reflections on Product Life Spans and the "Throwaway Society". Journal of Industrial Ecology, 9(1-2), 51-67. https://doi.org/10.1162/1088198054084671

Goodlad, J. I., Klein, M. F. \& Tye. K.A. (1979). The Domains of Curriculum and Their Study. In T. H. Quinn \& M. Hennelly (Eds.), Curriculum Inquiry: The Study of Curriculum Practice (pp. 43-76). McGraw-Hill Book Company.

Haugen, S. (Red.). (2019). Verkstedhåndbok for øvingsverkstedene på Institutt for produktdesign ved OsloMet storbyuniversitetet: HMS, maskiner og materialer, verkstedpraksis (Revidert utgave). http://hdl.handle.net/20.500.12199/2245

Høgskolen i Oslo og Akershus. (2017). Strategi 2024. https://www.oslomet.no/om/strategi-og-visjon

Kamp, L. (2006). Engineering education in sustainable development at Delft University of Technology. Journal of Cleaner Production, 14(9), 928-931. https://doi.org/10.1016/j.jclepro.2005.11.036

Kirke-, utdannings- og forskningsdepartementet. (1994). Læreplan for grunnskole, videregående opplæring og voksenopplæring. Generell del. http://www.pvv.org/ torfer/jam-rapport-og-evaluering/annet/L97laereplan-generell-del-bokmaal.pdf

Kunnskapsdepartementet. (2006). Læreplanverket for Kunnskapsløftet. https://www.nb.no/items/a9713c6622111b63c53947c7f01ee6f0?page=0\&searchText=kunnskapsl\%C3 \%B8ftet\%202006

Kunnskapsdepartementet. (2013). Forskrift om rammeplan for treårige faglærerutdanninger i praktiske og estetiske fag. https://lovdata.no/dokument/SF/forskrift/2013-03-18-290?q=fagl\%C3\%A6rerutdanning\%20design,\%20kunst\%20og\%20h\%C3\%A5ndverk.

Kunnskapsdepartementet. (2018). Forskrift om rammeplan for ingeniørutdanningen. https://www.regjeringen.no/contentassets/389bf8229a3244f0bc1c7835f842ab60/ny-forskrift-omrammeplan-for-ingeniorutdanning-fastsatt-18.05.18.pdf

Lozano, R., \& Young, W. (2013). Assessing sustainability in university curricula: exploring the influence of student numbers and course credits. Journal of cleaner production, 49, 134-141. https://doi.org/10.1016/j.jclepro.2012.07.032

Lozano, R. (2010). Diffusion of sustainable development in universities' curricula: an empirical example from Cardiff University. Journal of Cleaner Production, 18(7), 637-644. https://doi.org/10.1016/j.jclepro.2009.07.005

Meld. St.28 (2015-2016). Fag - fordypning - Forståelse. En fornyelse av Kunnskapsløftet. Kunnskapsdepartementet.https://www.regjeringen.no/contentassets/e8e1f41732ca4a64b003fca213ae 663b/no/pdfs/stm201520160028000dddpdfs.pdf.

Nielsen, L. M. (2019). Fagdidaktikk for Kunst og håndverk. I går, i dag, i morgen. Universitetsforlaget.

Opplæringsloven. (1998). Lov om grunnskolen og den vidaregåande opplæringa https://lovdata.no/dokument/NL/lov/1998-07-17-61

OsloMet. (2019a). OsloMet - Storbyuniversitetet. Langtidsplan og budsjett 2019-2021. https://ansatt.oslomet.no/documents/585743/54495365/Langtidsplan+og+-budsjett+20202020/a1091822-fbe2-88fb-3989-35e1b0434ea2

OsloMet. (2019b). Programplan for Bioteknologi- og kjemiingeniør. https://www.oslomet.no/studier/tkd/bioteknologi-kjemiingenior

OsloMet. (2019c). Programplan for Elektronikkingeniør. https://www.oslomet.no/studier/tkd/elektronikkingenior

OsloMet. (2019d). Programplan for Faglærer i design, kunst og håndverk. https://www.oslomet.no/studier/tkd/design-kunst-handverk

OsloMet. (2019e). Programplan for kompletterende ingeniør og teknologiutdanning. https://www.oslomet.no/studier/tkd/kompletterende-ingenior-teknologi

OsloMet. (2019f). Programplan for Maskiningeniør. https://www.oslomet.no/studier/tkd/maskiningenior 
OsloMet. (2020a). Bærekraftig utvikling for det 21. århundre. OsloMet handlingsplan for bærekraft 2021-2024. https://uni.oslomet.no/dengodestudentopplevelsen/wpcontent/uploads/sites/12/2020/06/Handlingsplan-b\%C3\%A6rekraft_2020_web.pdf

OsloMet. (2020b). Programplan for Energi og miljø i bygg. https://www.oslomet.no/studier/tkd/energi-miljo

OsloMet. (2020c). Programplan for Produktdesign. https://www.oslomet.no/studier/tkd/produktdesign

Papanek, V. (1971). Design for the Real World: Human Ecology and Social Change. Pantheon Books.

Sibbet, D. (2008). Team leader guide: strategies and practices for achieving high performance. The Grove Consultants International.

Thompson, R. (2007). Manufacturing processes for design professionals. Thames \& Hudson.

Thürer, M., Tomašević, I., Stevenson, M., Qu, T. \& Huisingh, D. (2018). A systematic review of the, literature on integrating sustainability into engineering curricula. Journal of Cleaner Production. 181, 608-617. https://doi.org/10.1016/j.jclepro.2017.12.130

UNESCO. (2014). Shaping the Future we Want. UN Decade of Education for Sustainable Development (2005-2014) FINAL REPORT. http://unesdoc.unesco.org/images/0023/002303/230302e.pdf

World Commission on Environment and Development. (1987). Our Common Future. Oxford university press.

\footnotetext{
${ }^{1}$ Programplanene på nettet revideres ofte og de er uten sidetall. Ved henvisning til programplanene har vi valgt å legge inn årstallet på den planen som er analysert. De ulike årenes programplaner med tilhørende emnebeskrivelser finnes under overskriften 'Programhistorikk' på nettsiden til hvert enkelt program. Fordi programplanene ikke har sidetall, har vi valgt å legge til emne i den løpende teksten for å synliggjøre hvor i programplanen sitatene er hentet fra.
} 